\title{
The Effect of District Health Spending on Disease Rates in Sumatra Island
}

\author{
${ }^{1}$ ESTRO DARIATNO SIHALOHO, ${ }^{2}$ DONNY HARDIAWAN, ${ }^{3}$ ACHMAD KAUTSAR ${ }^{4}$ CITRA \\ KUMALA ${ }^{5}$ DINDA AYU MAHARANI ${ }^{6}$ INSAN LUTFIANA ALFARIZY ${ }^{7}$ ADIATMA YM \\ SIREGAR
}

\author{
12,4,5,6,7Department of Economics, Faculty of Economics and Business, Universitas Padjadjaran \\ Jl. Raya Bandung Sumedang KM.21, Jatinangor, Sumedang Regency, West Java 45363 \\ ${ }^{3}$ Faculty of Economics and Business, Department of Economics, Universitas Pertamina \\ Jl. Teuku Nyak Arief, RT.7/RW.8, Simprug, Kec. Kby. Lama, Special Capital Region of Jakarta 12220 \\ email: ${ }^{*}$ estro.sihaloho@unpad.ac.id ; ${ }^{2}$ donnyhardiawan@gmail.com; \\ 3achmad.kautsar@universitaspertamina.ac.id; ${ }^{4}$ citrakmla@gmail.com; \\ ${ }^{5}$ dindayumhrn@gmail.com; ${ }^{6}$ insan.lutfiana@gmail.com; ${ }^{7}$ adiatma.siregar@unpad.ac.id \\ *Correspondence Authors : estro.sihaloho@unpad.ac.id
}

\begin{abstract}
This study aims to find the effect of district health spending on disease rates namely dengue fever, diarrhea, and tuberculosis in 130 districts in Sumatra Island in 2016. A quantitative approach with 3 multiple linear regression (MLR) methods that employ robust standard errors is used for this study. The study finds that district health spending reduces the number of dengue fever, diarrhea, and tuberculosis, but not significantly. This condition can be caused by the inefficient use of district health expenditure. This study finds the number of health centers has negative and significant effect on the number of dengue fever, diarrhea, and tuberculosis. Conversely, population and population density have a positive and significant effect on dengue fever, diarrhea, and tuberculosis. Economic losses due to diseases like dengue fever, diarrhea, and tuberculosis are very high. Therefore, the government must use effective and various policies to overcome the problem of existing diseases, one of which is to improve the efficiency of using the health budget. The government should also control birth rates to reduce population growth and encourage transmigration to reduce population density.
\end{abstract}

Keywords: District health spending, Disease rates, Effective policy

\section{Introduction}

Currently, the amount of health budget varies greatly among countries, with developing countries usually having relatively low share out of the government expenditure (Ke, Saksena, \& Holly, 2011). This is an important issue as health budget is one the important factors to overcome various health problems (Göpffarth \& Henke, 2013; Martin, Rice, \& Smith, 2008). The higher share of health expenditure may result in sustaining more health care workers. Or, et al. (2005) showed that a large number of doctors could improve health. The ratio of doctors to population in developed countries like the United States amounted to 35.67 doctors per 10,000 population in 2016 , whereas for developing countries like Indonesia, the ratio of doctors to population was only 4.27 doctors per 10,000 population in 2018 (WHO, 2020). In addition, the government's health assistance is largely important because it can help to ease the burden on the community to take medication (Manton, Gu, \& Lamb, 2006). Health budget should be focusing on ensuring that poor people can get access to better health services (Castro-leal et al., 2000). As one of the most populated country in the world, Indonesia's health spending is still relatively low. According to the WHO database in 2017, the proportion between the health spending and the GDP among

Received: June 01, 2020, Revision: October 12, 2020, Accepted: June 28, 2021

Print ISSN: 0215-8175; Online ISSN: 2303-2499. DOI: https://doi.org/10.29313/mimbar.v37i1.6224

Accredited Sinta 2 based on the decree No.10/E/KPT/2019 until 2024. Indexed by DOAJ, Sinta, Garuda, Crossreff, Dimensions 
numerous low-to-medium income countries are remain below the average roughly at $2.8 \%$ of the GDP in 2014 (Mahendradhata et al., 2017).

Funds provided by the government are distributed to all provinces in Indonesia in accordance with the number of population and health needs of each province. Unfortunately, provinces do not always effectively use the fund. In 2016, with a population of $14,102,991$, Sumatra Utara received funds of around Rp.98.6 billion and was only used at $58.40 \%$. The province of Sumatra Selatan with $8,160,901$ populations received Rp.64.8 billion health funds and was used at $61.59 \%$. While Sumatra Barat with 5,259,528 populations received approximately Rp.59.4 billion was used $53.84 \%$ (Ministry of Health, 2017). The inequality of health spending in Sumatra Island districts was still high. In 2016, the highest expenditure was Batang Hari District with 368 billion rupiah and the lowest was Southeast Aceh District with 4.4 billion rupiah.

Dengue fever or dengue is an old disease; it was first recorded during the Chin Dynasty and written in a Chinese encyclopedia (265-420AD). Although recorded when medical knowledge was still ancient, the Chinese had already known that the disease was related to flying insect and water; hence called it a water poison disease (Gubler \& Clark, 1995). A dengue-like epidemic was recorded in Batavia (now Jakarta) as early as 1779 , but it was not confirmed as dengue fever (Carey Donald. E., 1971). There are four distinctive stereotypes of the virus, such as the DEN-1, DEN-2, DEN-3, and DEN-4 which each infection from any of these four will not make the person immune from the rest, thus a person can potentially have four dengue infections during their lifetime. Typically occurring in the tropics, this disease can produce various clinical illnesses heavily dependent on the strain and the stereotype of the virus itself, the immune system and disorders, the age of the patient infected, and the genetic predisposition of the infected (Gubler \& Clark, 1995). Dengue fever is a contagious disease and can cause death in a short time. Ministry of Health in 2010 reported that dengue fever sufferers would develop along with population growth and mobility and population density (Siregar, 2004).

Much like dengue fever, diarrhea has been around since medieval times. To pinpoint where it first started is impossible, but epidemics as early as the Plague of Athens, occurring in 430 BC was characterized by diarrhea. Since then, diarrhea has been a disease that greatly impacts nations and war as late as the 1991 Gulf War (Lim \& Wallace, 2004). Even now, diarrhea still accounts for more than 2 million deaths every year (Thielman \& Guerrant, 2004). A single virus or bacterium does not cause infectious diarrhea. Instead, there are several types of diarrhea: bacterial, viral, and parasitic. Each type of diarrhea has different mechanisms and affects different cellular functions with research still ongoing to understand them, as they require different treatments (Hodges \& Gill, 2010). According to the Ministry of Health in 2018, diarrhea is a type of disease that can cause death in infants. Diarrhea can also be transmitted quickly through unclean environments and consuming dirty water (Ragil \& Dyah, 2017).

Tuberculosis (TB) is a type of infectious disease. The disease is caused by Mycobacterium Tuberculosis-a bacterium which able to infect the body especially the lungs. WHO reported the number of TB cases was still high. In 2017, it was estimated that 1.7 billion people were infected with Mycobacterium tuberculosis (Houben \& Dodd, 2016). This disease is included of the nine main causes of death in the world higher than HIV/AIDS. Every year, an average of ten million people worldwide was dead from tuberculosis. Tuberculosis, especially in many developing countries, is selected as one of the most problematic global health condition, including in Indonesia (Jamison, Breman, Measham, Alleyne, \& Claeson, 2006). Indonesia ranks as the second among the highest number of tuberculosis cases in the world following India as the first. It can be indicated by new tuberculosis cases found in Indonesia in 2016. The tuberculosis incidence in Indonesia is estimated at around 360,770 people in 2017, higher than the previous year which reached 351,893 people 2021/6/14.

Data of three common diseases in Indonesia (TB, dengue, and diarrhea) showed that cities/districts in Sumatra Island have high rates (Badan Pusat Statistik, 2017). The average number of new cases of dengue fever are 221 cases with a total of about 29 thousand new cases in all cities/districts on Sumatra Island. The average number of new cases of diarrhea is higher, at 6.9 thousand cases with a total of about 905 thousand new 
cases in all districts of Sumatra Island. While the average of new tuberculosis cases are 363 cases with a total of about 47 thousand new cases in all cities/districts in Sumatra Island (Badan Pusat Statistik, 2017)

Given the relatively high health budget inequality and the number of TB, dengue, and diarrhea cases in cities/districts in Sumatra Island, this study's intention is to analyze how each city/districts health spending affected the number of disease cases in respective cities/districts in Sumatra Island.

\section{Research Methodology}

A quantitative approach with a multiple linear regression (MLR) method that employs robust standard errors is used in this study. Wooldridge (2015) stated that the aforementioned method provides control to the problematic factors such as outliers, non-randomness of sampling, and multicollinearity that affects dependent variable explicitly (Wooldridge, 2015). As for the heteroskedasticity-robust standard errors-also known as Huber-White standard error-the technique assumed that even though there is an existence of heteroskedasticity (where error term's variance is not the same across the data) within the error, the model can still be corrected when the error term's variance () is replaced by the OLS residuals from the initial regression of $y$ on $x()$ during the computation of the estimated parameter's variance ( (White, 1980).

A secondary dataset provided by Badan Pusat Statistik (BPS) in 2017 on health spending, dengue cases, diarrhea cases, tuberculosis cases, number of primary health care, number of the population, and population density in 130 districts within 8 provinces in Sumatera Island, Indonesia is used for this study. We assumed that there is a normal distribution within the data, which could turn into troubles due to differences in the pattern-or even without pattern at all, of the data between samples in reality. Thus, there are more reasons to use a robust regression technique that fits a model which describes information in the majority of data, implying that it would work well on data both with or without outliers (Alma, 2011).

The collected data from every 130 cities'/regencies' Badan Pusat Statistik was modeled with the general multiple linear regression models that theoretically written by Wooldridge (2015) as:

$$
y=\beta_{0}+\beta_{1} x_{1}+\cdots+\beta_{k} x_{k}+u,
$$

where $\beta \_0$ is the intercept of the model, is the parameter associated with explanatory variable and respectively along with the other parameters and variables. Meanwhile is the error term or disturbance which contains factors outside the model that affect other than $\mathrm{x} \_1, \mathrm{x} \_2, \ldots, \mathrm{x} \_\mathrm{k}$. . The key assumptions (although some are not strongly assumed) of this model requires ( $i$ ) that parameters have to be linear, (ii) the sample has to be collected randomly, (iii) no perfect collinearity among independent variables, (iv) the error term expected value should be zero given any value of the independent variables, and $(v)$ each factor in the unobserved error term has to be uncorrelated with the explanatory variables (Wooldridge, 2015) which could be elaborated mathematically as:

$$
E\left(u \mid x_{1}, x_{2}, \ldots, x_{k}\right),
$$

Concerning the purpose of this studyto find whether there is any significant effect between the health spending on three diseases case in each district studied. As the result, the dependent variables in this study are the three mentioned diseases above: Dengue, Diarrhea, and TB Case. Concurrently, the main target variable is the Health Budget, while the rest of the independent variables that act as a control for the models are Primary Health Care Number and Population Density. Therefore, the model used in this study should be translated to:

\section{Dengue/ Diarrhea/TB Cases $=\beta_{0}+$ $\beta_{1}$ Health Budget + $\beta_{2}$ Primary Health Care Number + $\beta_{3}$ Population Density $+u$,}

The three diseases in front of the model written above indicate that there are three (3) models, respectively for each disease in this study.

\section{Result and Discussion}

The data comprises 130 districts in 2016. Our data shows that the biggest health budget is in the Batang Hari Regency at 368 billion rupiahs and the smallest health budget is in Aceh Tenggara regency 
with a little less than 4.5 billion Rupiah. On average, the health budget for all districts in Sumatra Island is about 117.5 billion Rupiah. In terms of dengue cases, regions range from one case to a whopping 1,144 cases in a region, with each region having 221.8 cases on average. The range is even larger for diarrhea cases, with regions reporting no incidence to 41,834 cases. On average, each region has 6,913 cases. There is no region without a TBC case, it ranges from 20 cases to 3,915 cases with an average of 363 cases.

Table 1.

\section{Descriptive Statistics ( $N=130$ cities / districts)}

\begin{tabular}{lrrr}
\hline VARIABLES & mean & min & max \\
\hline $\begin{array}{l}\text { Health Spending } \\
\text { ((Billion Rp }\end{array}$ & 117.6 & 4.4 & 368.4 \\
$\begin{array}{l}\text { Dengue cases } \\
\text { Diarrhea cases }\end{array}$ & 221.8 & 1 & 1,144 \\
TBC cases & 6,913 & 36 & 41,834 \\
$\begin{array}{l}\text { Primary Health } \\
\text { Care number }\end{array}$ & 16.97 & 4 & 3,915 \\
$\begin{array}{l}\text { Population } \\
\text { ((people }\end{array}$ & 362,891 & 33,622 & $2,072,521$ \\
$\begin{array}{l}\text { Population } \\
\text { density (people/ } \\
\text { (km² }\end{array}$ & 531.3 & 16 & 5,126 \\
\hline \multicolumn{1}{c}{ Source: (Badan Pusat Statistik, 2017) }
\end{tabular}

The minimum and the maximum number of primary health care are 4 and 39 respectively, with 16 on average. The population is not spread evenly over the island, as a region only has a population of
33,622 while another region has two million of population. On average, Sumatra Island Districts are populated by 362,891 people. The population density is also vastly different, as the least dense region has a population density of 16 people per $\mathrm{km}^{2}$, and the most densely populated region has 5,126 people per $\mathrm{km}^{2}$. On average, the population density on the island of Sumatra is 531 people per $\mathrm{km}^{2}$.

Table 2 shows that government health expenditure negatively affects the number of dengue fever cases. Particularly, every rise of government health expenditure by 1 Rupiah will be reflected by a drop of the number of dengue fever by 0.26 case-all else kept equals. However, government health expenditure does not significantly affect the number of dengue cases. However, the number of primary health care in the cities/ districts has a significant negative effect on the number of dengue fever events. With a significance level of 1 percent, when the number of primary health care increases by 1 unit, the number of dengue fever events will decrease by 7.48 , ceteris paribus.

The population has a significant positive effect on the number of dengue fever events. With a significance level of 1 percent, when the population increases by one population, the number of dengue fever events will increase by 0.00069 , ceteris paribus. Population density has a significant positive effect on the number of dengue cases. With a significance level of 10 percent, when the population density increases by 1

Table 2.

Regression Result of Dengue cases

\begin{tabular}{|c|c|c|c|c|}
\hline & & Num of obs & $=$ & 130 \\
\hline & & $F(4,125)$ & $=$ & 37.17 \\
\hline & & Prob $>$ F & $=$ & 0.0000 \\
\hline & & $\mathrm{R}^{2}$ & $=$ & 0.5433 \\
\hline & & Adj $R^{2}$ & $=$ & 0.5287 \\
\hline & & Root MSE & $=$ & 162.9 \\
\hline Dengue cases & Coef & Std. Err & $\mathrm{t}$ & $P>|t|$ \\
\hline Health_Spending & -0.26767 & 0.381652 & -0.70 & 0.484 \\
\hline $\begin{array}{l}\text { Primary Health Care } \\
\text { number*** }\end{array}$ & -7.48067 & 2.878494 & -2.60 & 0.010 \\
\hline Population $* * *$ & 0.000689 & $7.45 \mathrm{E}-05$ & 9.25 & 0.000 \\
\hline Population density* & 0.026793 & 0.014025 & 1.91 & 0.058 \\
\hline _cons & 102.5935 & 47.0321 & 2.18 & 0.031 \\
\hline
\end{tabular}

$* \mathrm{p}<0.1, * * \mathrm{p}<0.05, * * * \mathrm{p}<0.01$ 
unit, the number of dengue fever cases will increase by 0.027 , ceteris paribus.

Table 3 shows that government health expenditure has a negative effect on the number of diarrhea cases. In other words, when the government funds more the health expenditure by 1 Rupiah, the number of diarrhea cases will drop by 1.50 , ceteris paribus. However, government health expenditure does not significantly affect the number of diarrhea cases. The number of primary health care has a significant negative effect on the number of diarrhea cases. With a significance level of 1 percent, when the number of primary health care increases by 1 unit, the number of diarrhea events will decrease by 230 , ceteris paribus.

The population has a significant positive effect on the number of diarrhea cases. With a significance level of 1 percent, when the population increases by one population, the number of diarrhea events will increase by 0.0238466 , ceteris paribus. Population density has a significant positive effect on the number of dengue cases. With a significance level of 1 percent, when the population density increases by 1 unit, the number of diarrhea cases will increase by 1.363839 , ceteris paribus.

Table 4 shows that government health expenditure has a negative effect on the number of tuberculosis cases. In other words, when an increase in government health expenditure by 1 Rupiah will lower the number of tuberculosis cases by 0.26 cases, ceteris paribus. However, government health expenditure does not significantly affect the number of tuberculosis cases. The number of primary health care has a significant negative effect on the number of tuberculosis cases. With a significance level of 1 percent, when the number of primary health care increases by 1 unit, the number of tuberculosis cases will decrease by 15 , ceteris paribus.

The number of populations affects significantly the number of tuberculosis cases. With a significance level of 1 percent, when there is an increase in the number of citizens by one person, the number of the infected by the tuberculosis cases will rise by 12 , ceteris paribus. Population density has a significant positive effect on the number of dengue cases. With a significance level of 5 percent, when the population density increases by 1 unit, the number of tuberculosis cases will increase by 0.0122552 , ceteris paribus.

\section{Dengue Fever}

A study has found that dengue fever occurs in clusters in populated areas (Kusuma \& Sukendra, 2016). Dengue fever seems to be concentrated in more populated areas in a study done in Karangmalang, while in less dense areas, there is less of a cluster (Setyaningsih \& Setyawan, 2014). A spatial study in Bandung also found that population density is related to diarrhea (Tantular, Nurfauziyah, Jaya, \& Zulhanif, 2007). The study used spatial regression with the percentage of healthy houses and population density as predictors, finding that both are significant. Tuberculosis, in particular, is heavily influenced by how well

Table 3.

Regression Result of Diarrhea cases

\begin{tabular}{|c|c|c|c|c|}
\hline \multirow[b]{7}{*}{ Diarrhea cases } & & Num of obs & $=$ & 130 \\
\hline & & $F(4,125)$ & $=$ & 44.99 \\
\hline & & Prob $>\mathrm{F}$ & $=$ & 0.0000 \\
\hline & & $\mathrm{R}^{2}$ & $=$ & 0.5901 \\
\hline & & Adj $R^{2}$ & $=$ & 0.5770 \\
\hline & & Root MSE & $=$ & 5022.3 \\
\hline & Coef & Std. Err & $\mathrm{t}$ & $P>|t|$ \\
\hline Health_Spending & -1.50309 & 11.76688 & -0.13 & 0.899 \\
\hline $\begin{array}{l}\text { Primary Health Care } \\
\text { number*** }\end{array}$ & -230.893 & 88.74822 & -2.60 & 0.010 \\
\hline Population $* * *$ & 0.023847 & $2.30 \mathrm{E}-03$ & 10.38 & 0.000 \\
\hline Population density*** & 1.363839 & 0.432413 & 3.15 & 0.002 \\
\hline _cons & 3025.156 & 1450.069 & 2.09 & 0.039 \\
\hline
\end{tabular}

$* \mathrm{p}<0.1, * * \mathrm{p}<0.05, * * * \mathrm{p}<0.01$ 
MIMBAR, Vol. 37, No. $1^{\text {st }}$ (June, 2021), pp. 12-23

Table 4.

Regression Result of TBC Cases

\begin{tabular}{lcccr}
\hline & & Num of obs & $=$ & 130 \\
& & $\mathrm{~F}(4,125)$ & $=$ & 61.37 \\
& & Prob $>\mathrm{F}$ & $=$ & 0.0000 \\
& & $\mathrm{R}^{2}$ & $=$ & 0.6626 \\
& & Adj R & $=$ & 0.6518 \\
& & Root MSE & $=$ & 258.65 \\
\hline TBC cases & Coef & Std. Err & $\mathrm{t}$ & $\mathrm{P}>|\mathrm{t}|$ \\
Health_Spending & -0.26167 & 0.60599 & 0.43 & 0.667 \\
Primary Health Care & -15.0451 & 4.570499 & -3.29 & 0.001 \\
number*** & 0.001443 & $1.18 \mathrm{E}-04$ & 12.2 & 0.000 \\
Population*** & 0.012255 & 0.222691 & 2.55 & 0.001 \\
Population density*** & 71.38413 & 74.678 & 0.96 & 0.341 \\
\hline cons & $* .1, * * \mathrm{p}<0.05, * * * \mathrm{p}<0.01$ & &
\end{tabular}

a house is ventilated. Living in a dense and highly populated neighborhood causes individuals to be more susceptible to TBC. These houses usually have bad ventilation and do not get sunlight, a prime condition for the bacteria to breed (Kustin \& Akib, 2013; Pratama \& Wulandari, 2015).

In many tropical countries, dengue fever is one of the notable public health concerns (Ali \& Ma'Rufi, 2018). Our analysis results prove that there is no significant effect from government health spending on reducing dengue cases. Kamila (2017) shows the dengue program budget is allocated more for health administrative activities than public health activities for the dengue program, which has an impact on not achieving the goals of eradicating the dengue. Furthermore, Puskesmas as the Primary Health Care in Indonesia, plays a role in organizing public health development in each region, does not have its budget to carry out dengue eradication activities but instead uses budgets sourced from the Regional Health Office. Puskesmas should have their funds for the dengue eradication program. If there is an urgent activity, the Puskesmas can disburse funds more quickly without having to submit a funding request to the District Health Office which requires more time (Kamila, 2017).

Studies have shown that climate condition such as rainfall seasons and the precipitation intensity across the area contribute to a higher dengue incidence. In other words, dengue fever is a seasonal disease whose number of sufferers will increase along with the increase in rainfall that occurs (Ali \& Ma'Rufi, 2018; Thammapalo, Chongsuwiwatwong, McNeil, \& Geater, 2005). Future studies are suggested to predict the time at which dengue's prevalence will increase, so the budget can be used at the right time.

\section{Diarrhea}

Diarrhea is also important to be overcome by the government. Ministry of Health in 2018 reported that diarrhea is a disease that can cause the death of infants. Diarrhea can also be transmitted quickly through unclean environments and consuming dirty water (Ragil \& Dyah, 2017). In the category of other types of diseases that can cause death, diarrhea and dengue fever are included. The mortality ratio caused by diarrhea has increased every year as seen from 2017; the mortality ratio in 2017 was around $1.97 \%$ and $4.76 \%$ in 2018. This disease is still dangerous because the handling of diarrhea cases is still below $50 \%$ (Ministry of Health, 2019).

\section{Tuberculosis}

The prevention of tuberculosis must be done seriously. One effort to end tuberculosis is through social protection programs. For developed countries investing in social protection programs is an effective way to prevent tuberculosis (Reeves et al., 2014). Generally developed countries like European countries have high budgets for social protection programs. This condition can be 
seen through the allocation of GDP to social protection programs that reach more than 20 percent. Things went differently in the developing countries, where the government only allocate less than 10 percent of the total GDP to the social protection policy. Different things happen in developing countries that only allocate less than 10 percent of total GDP to social protection programs. Therefore, developing countries have a high prevalence of tuberculosis, including in Indonesia (Siroka, Ponce, \& Lönnroth, 2016).

Sumatra island has a large population of $21.80 \%$ among the population in Indonesia with the highest percentage of poor people in Sumatra Selatan as much as $12.82 \%$, Sumatra Utara as much as 8.94, and Sumatra Barat as much as $6.55 \%$ (Ministry of Health, 2019). One of the provinces on the island of Sumatra that suffer from TB in 2018 is Sumatra Selatan, accounting for $50.1 \%$ of the total population. It is the province with the highest number of TB patients on the island of Sumatra, although the success rate of treatment is $95.1 \%$ where the success rate has exceeded the target set at $90 \%$. Based on research conducted in Palembang, a high rate of TB was caused by a lack of knowledge about the spreading of TB disease (Budi, Ardillah, Sari, \& Septiawati, 2018).

\section{Health Spending}

Government health expenditure is eminently important in overcoming health problems. However, many factors affect the government's success in using the budget appropriately and overcoming the number of diseases in a region. This study found a negative but not significant effect between health spending and disease rates. An insignificant relationship between health spending and number of diseases can be caused by the inefficient use of health budgets. Inefficient use of the budget can be caused by corruption and the quality of public institutions that are not optimal (Novignon, 2015). To achieve efficiency, improvements are needed in the healthcare system such as allocating the resources with optimized means and by improving the allocation of financial resources within the system (Liu, Xia, \& Hou, 2019)China is faced with the daunting challenge of maintaining equality and efficiency in health resource allocation and health services utilization in the context of rapid economic growth in rural areas. The reasonable allocation of limited rural health resources may be achieved by scientifically measuring the current rural HEE. This subject may help to formulate effective policy or provide incentives for the health sector. Methods: The combination of a superslack-based measure (SBM. Technology can be used by the government as a means to enhance the extent of the optimization levels (Liu et al., 2019)China is faced with the daunting challenge of maintaining equality and efficiency in health resource allocation and health services utilization in the context of rapid economic growth in rural areas. The reasonable allocation of limited rural health resources may be achieved by scientifically measuring the current rural HEE. This subject may help to formulate effective policy or provide incentives for the health sector. Methods: The combination of a super-slack-based measure (SBM. The increase in scale optimization will accelerate the resolution of health problems in an area. Administrative expenditure is also one of the causes of inefficient health spending. A lower health care productivities are often rooted in problematic administrative expenses (Garber \& Skinner, 2008). Lower health care productivity causes insignificant effects of health spending to reduce the rate of disease in some districts.

\section{Primary Health Care}

From the results of the regression for each prevalent disease across 130 different districts in Sumatra, the study found that the number of primary health care, the number of populations, and the population density affect the incidence rate of dengue fever, diarrhea, and TBC in each district. From the four variables used as predictors, only the health budget does not significantly affect all three diseases. Taking from a study done in Aceh Besar region, this might be in the execution of the health programs and where the budget is allocated rather than the amount of budget allocated (Murdani \& Suherlan, 2014). The efficiency ratio in the health budget is found to be inefficient from 2008-2012. The budget given to the region is not handled well with some money lost due to corruption as well as suboptimal planning. The money is used, but the results are not optimum.

Another study done in Sumatra Barat cited that the lack of budget management training, as well as the weak coordination between stakeholders, made it ineffective (Kani, Herawati, \& Trisnantoro, 2012). The planning does not involve primary health 
care as the primary health care provider. Therefore, the execution and the budget for several programs in primary health care clash. The budgeting team constantly revises the planned budget made by the Sumatra Barat Public Health Office because of budgeting limitations. The health budget realization for the 2006, 2007, and 2008 is fairly low. From these two studies, we can conclude that the budget realization is low because of poor planning and budget limitations. Yet, when this budget is realized, it's not used effectively.

The number of primary health care in each district has a negative relationship with the number of cases found, all significant at $1 \%$ significance level. On average, one public health center reduces dengue fever by 7 cases, diarrhea by 230 cases, and TBC by 15 cases. The Minister of Health Decree No. 128 the Year 2004 about the basic policy of Public Health Center state that the ideal ratio between the number of the public health center and population of a region is ideally $1: 30,000$ but the development has been hindered by the lack of monitoring and faulty execution (Menteri Kesehatan Republik Indonesia, 2004; Winarno et al., 2013). In accordance with the decree, this primary health care provides not only healthcare but also information on hygiene and healthy living. More primary health cares make shorter lines and easier access for those living in rural areas, motivating individuals to seek health advice instead of ignoring minor diseases such as diarrhea that may be more serious than it seems.

\section{Population}

The population influences the spread of TBC, diarrhea, and dengue fever in some way. As seen from a study in the Minahasa Utara region (Faldy, Kaunang, \& Pandelaki, 2015), the more populated districts (Kauditan, Airmadidi, and Kalawat) all have the highest incidence of dengue fever. The same case happens in the TBC occurrence of Jombang region, with the more populous districts having a greater number of cases. Similarly, the most populous district in Bandung city also has the most diarrhea (Badan Pusat Statistik, 2018; Tantular, Ruslaela, Jaya, \& Zulhanif, 2018). More populated regions pose the risk of dense neighborhoods, increasing the risk of infection spreading among the neighborhoods.

For the relationship between population and the number of dengue fever, diarrhea, and TBC cases found, the results are positive. The results mean that the more population a district has, the more cases of diarrhea, dengue fever, and TBC they will have. This is significant at $1 \%$ and in line with the previously mentioned studies where more populous areas tend to have more incidence of dengue fever, diarrhea, and TBC (Faldy et al., 2015; Pratama \& Wulandari, 2015; Tantular et al., 2018). More populated areas generally have dense housing that may speed up the spread of the disease, on top of unfavorable living conditions. Thus, we cannot take away the issue of the population from density.

\section{Population Density}

From the regression results, population density's effect is significant but positive at different levels for each disease. Diarrhea, which is highly related to hygiene in one's neighborhood, is at $1 \%$ significant level. As a disease, diarrhea spreads very fast in a short time and it's heavily dependent on health behaviors as well as sanitation. Neighborhoods can influence an individual's health habits (Diez-Roux et al., 2017) and a neighborhood without a proper toilet may put the whole neighborhood at risk (Boadi \& Kuitunen, 2002; Kamilla, Suhartono, \& W, 2012). The results are in line with previous research using population density to predict the risk of diarrhea incidence in Bandung city (Tantular et al., 2007).

This is followed by TBC which is significant at $5 \%$. The denser population means more people live in small unventilated houses with little to no sunlight exposure, a perfect place forTBC to breed. An overcrowded house also means easier transmission between household members. Another factor that may influence is that individuals in overcrowded housing are more likely to have risk factors that progress TB infections to disease (M. Clark, Riben, \& Nowgesic, 2002). Meanwhile, the effect of population density on the incidence of dengue fever is significant at $10 \%$. Dengue fever occurs in clusters in populated areas, making it easier to spread in dense neighborhoods (Kusuma \& Sukendra, 2016).

\section{The Economic Side}

Most of the studies that investigated the effect of dengue fever on the economy have overlooked the burden of the disease on the population, thus undervalued the true economic impact of dengue fever (Gulber, 
2002). A study of treated dengue cases in Puerto Rico from 2002 to 2010 found that the overall annual cost of dengue was US $\$ 46.45$ million (Halasa, Shepard, \& Zeng, 2012). The study also found that household bears the largest burden in the economic cost of dengue (48\%) compared to the government (24\%) and insurance $(22 \%)$. Another study sought to measure the economic impact of dengue at the household level in Thailand and found that there is a financial loss of US\$61 for every family (D. V. Clark, Mammen, Nisalak, Puthimethee, \& Endy, 2005)the impact of symptomatic dengue virus infection on the families of patients hospitalized at the Kamphaeng Phet Provincial Hospital with laboratory-confirmed dengue in 2001 was assessed, and the disability-adjusted life years (DALYs. Both the studies mentioned above account for the opportunity cost that may arise from dengue fever.

To find the overall impact of diarrhea on the economy is impossible as diarrhea has different causes and is often a symptom of a more serious disease. However, finding the impact of specific types of diarrhea is still possible. Rotavirus diarrhea, a type of viral diarrhea that heavily affects children, is estimated to cause around 454,000 to 705,000 deaths in children from 2000 to 2004 (Parashar, Gibson, Bresee, \& Glass, 2006). In Taiwan, rotavirus-associated hospital admission costs US $\$ 10.4$ million for hospital costs with an additional $\$ 13.3$ million of social cost annually (Chen et al., 2007). Diarrhea caused by the same virus imposes US $\$ 271.4$ million in annual direct cost, US\$365.0 million in annual social cost, and US\$290.0 in annual private cost in eastern China (Jin et al., 2011).

The impact of tuberculosis on the economy in most developing countries is not only problematic because of the scale of the incidence, rather that the majority of the infected and death occurrence develops in the most economically active segment of the population (Ahlburg, 2000). A study in the Philippines found that the country is economically burdened by approximately US $\$ 145$ million due to tuberculosis' premature mortality and morbidity. Meanwhile, the cost of treating the cases is between US $\$ 8$ to US $\$ 29$ million annually (Peabody, Shimkhada, Tan, \& Luck, 2005) carried out between 1997 and 2001 in the Philippines, were used to: (1. In Indonesia, the total economic burden of treated and untreated cases adds up to US $\$ 6.9$ billion, with loss of productivity from premature death being the biggest portion at US $\$ 6.0$ billion (Collins, Hafidz, \& Mustikawati, 2017). Tuberculosis also affects economic growth, corresponding to an annual loss of US $\$ 1.4$ to 2.8 billion worldwide (Grimard \& Harling, 2005).

\section{Conclusion}

Economic losses due to diseases like dengue fever, diarrhea, and tuberculosis are very high. Therefore, the government must use various policies to overcome the problem of existing diseases in the community. This research shows that health spending still has no a significant effect in reducing the number of dengue fever, diarrhea, and tuberculosis in Sumatera Island districts. This can be caused by the inefficient use of the health budget. For this reason, the government needs to improve the efficiency of using the health budget. The government can increase the number of health services such as primary health care because it significantly reduced the number of dengue fever, diarrhea, and tuberculosis. The study also found that population and population density increase dengue fever, diarrhea, and tuberculosis rates. The government must control birth rates to reduce population growth and encourage transmigration to reduce population density.

\section{References}

Ahlburg, D. A. (2000). The Economic Impacts of Tuberculosis.

Ali, K., \& Ma'Rufi, I. (2018). The relationship between rainfall and dengue hemorrhagic fever incidence during 2009-2013 (Case study at Grati and Tutur Sub-district, Pasuruan, Indonesia). In IOP Conference Series: Earth and Environmental Science. https://doi.org/10.1088/17551315/200/1/012031

Alma, Ö. G. (2011). Comparison of Robust Regression Methods in Linear Regression. Int. J. Contemp. Math. Sciences, 6(9), 409-421.

Badan Pusat Statistik. (2017). Statistik Indonesia.

Badan Pusat Statistik. (2018). Kota Bandung dalam Angka.

Boadi, K. O., \& Kuitunen, M. (2002). Childhood diarrheal morbidity in the Accra Metropolitan Area, Ghana: 
Socio-economic, environmental and behavioral risk determinants, (January 2016). https://doi.org/10.12927/ whp. 2005.17646

Budi, I. S., Ardillah, Y., Sari, I. P., \& Septiawati, D. (2018). Analisis Faktor Risiko Kejadian penyakit Tuberculosis Bagi Masyarakat Daerah Kumuh Kota Palembang. Jurnal Kesehatan Lingkungan Indonesia, $17(2)$, 87. https://doi.org/10.14710/ jkli.17.2.87-94

Carey Donald. E. (1971). Chikungunya and dengue: a case of mistaken identity? Journal of the History of Medicine and Allied Sciences, 26(3), $243-262$.

Castro-leal, F., Castro-leal, F., Dayton, J., Dayton, J., Demery, L., Demery, L., ... Mehra, K. (2000). Public spending on health care in Africa: do the poor benefit? Bulletin of the World Health Organization, (0201), 9.

Chen, K. T., Fan, S. F., Tang, R. Bin, Huang, Y. F., Lee, P. I., Chen, P. Y., ... Chen, H. C. (2007). Hospital-based study of the economic burden associated with rotavirus diarrhea in Taiwan. Vaccine, 25(21), 4266-4272. https://doi. org/10.1016/j.vaccine.2007.02.056

Clark, M., Riben, P., \& Nowgesic, E. (2002). The association of housing density, isolation and tuberculosis in Canadian First Nations communities. International Journal of Epidemiology, 31(5), 940-945. https://doi.org/10.1093/ije/31.5.940

Clark, D. V., Mammen, M. P., Nisalak, A., Puthimethee, V., \& Endy, T. P. (2005). Economic impact of dengue fever/ dengue hemorrhagic fever in Thailand at the family and population levels. American Journal of Tropical Medicine and Hygiene, 72(6), 786-791. https:// doi.org/10.4269/ajtmh.2005.72.786

Collins, D., Hafidz, F., \& Mustikawati, D. (2017). The economic burden of tuberculosis in Indonesia. International Journal of Tuberculosis and Lung Disease, 21(9), 1041-1048. https://doi. org/10.5588/ijtld.16.0898

Diez-Roux, A. V., Javier Nieto, F., Muntaner, C., Tyroler, H. A., Comstock, G. W., Shahar, E., ... Szklo, M. (2017). Neighborhood Environments and Coronary Heart Disease: A Multilevel Analysis. American Journal of Epidemiology, 185(11), 11871202. https://doi.org/10.1093/aje/ $\mathrm{kw} \times 113$

Faldy, R., Kaunang, W. P. J., \& Pandelaki,
A. J. (2015). Pemetaan Kasus Demam Berdarah Dengue di Kabupaten Minahasa Utara. Jurnal Kedokteran Komunitas Dan Tropik, 3(2), 73-81.

Garber, A. M., \& Skinner, J. (2008). Is American health care uniquely inefficient? In Journal of Economic Perspectives. https://doi.org/10.1257/jep.22.4.27

Göpffarth, D., \& Henke, K. D. (2013). The German Central Health Fund-Recent developments in health care financing in Germany. Health Policy, 109(3), 246-252. https://doi.org/10.1016/j. healthpol.2012.11.001

Grimard, F., \& Harling, G. (2005). The Impact of Tuberculosis on Economic Growth. https:// doi.org/10.1111/j.1536-7150.1957. tb00182.x

Gubler, D. J., \& Clark, G. G. (1995). Dengue/dengue hemorrhagic fever: the emergence of a global health problem. Emerging Infectious Diseases, 1(2), 55-57. https://doi.org/10.3201/ eid0102.952004

Gulber, D. J. (2002). Epidemic dengue/ dengue hemorrhagic fever as a public health, social and economic problem in the 21st century. Trends in Microbiology, 10(2), 100-103.

Halasa, Y. A., Shepard, D. S., \& Zeng, W. (2012). Economic cost of dengue in Puerto Rico. American Journal of Tropical Medicine and Hygiene, 86(5), 745-752. https://doi.org/10.4269/ ajtmh.2012.11-0784

Hodges, K., \& Gill, R. (2010). Infectious diarrhea: Cellular and molecular mechanisms. Gut Microbes, 1(1), 4-21. https://doi.org/10.4161/gmic.1.1.11036

Houben, R. M. G. J., \& Dodd, P. J. (2016). The Global Burden of Latent Tuberculosis Infection: A Re-estimation Using Mathematical Modelling. PLoS Medicine, 13(10), 1-13. https://doi.org/10.1371/ journal.pmed.1002152

Jamison, D. T., Breman, J. G., Measham, A. R., Alleyne, G., \& Claeson, M. (2006). Disease Control Priorities in Developing Countries. Disease Control Priorities in Developing Countries (2nd Edition). https://doi.org/10.1596/978-0-82136179- 5

Jin, H., Wang, B., Fang, Z., Duan, Z., Gao, Q., Liu, N., ... Wu, Q. (2011). Hospital-based study of the economic burden associated with rotavirus diarrhea in eastern China. 
Vaccine, 29(44), 7801-7806. https:// doi.org/10.1016/j.vaccine.2011.07.104

Kamila, N. (2017). Analisis Pembiayaan Program Promotif dan Preventif Pemberantasan Demam Berdarah Dengue (DBD) Bersumber Pemerintah di Kota Semarang Tahun 2013-2015. Jurnal Ekonomi Kesehatan Indonesia. https:// doi.org/10.7454/jurnal-eki.v2i1.1953

Kamilla, L., Suhartono, \& W, N. E. (2012). Hubungan Praktek Personal Hygiene Ibu dan Kondisi Sanitasi Lingkungan Rumah dengan Kejadian Diare pada Balita di Puskesmas Kampung Dalam Kecamatan Pontianak Timur The Relationship of Maternal Personal Hygiene and Housing Environmental Sanitation to Pontia. Jurnal Kesehatan Lingkungan Indonesia, 11(2).

Kani, A., Herawati, D. M. D., \& Trisnantoro, L. (2012). Evaluasi Perencanaan dan Penganggaran Dinas Kesehatan Kabupaten Pesisir Selatan Provinsi Sumatera Barat. Jurnal Manajemen Pelayanan Kesehatan, 15(03), 131-139.

Ke, X., Saksena, P., \& Holly, A. (2011). The determinants of health expenditure: a country-level panel data analysis. Geneva: World Health Organization, 26.

Kustin, \& Akib, H. (2013). Hubungan Ventilasi dan Kepadatan Hunian dengan Penularan Silang TBC Paru dalam Keluarga. Jurnal Kesehatan Dr. Soebandi, 6(1), 523-529.

Kusuma, A. P., \& Sukendra, D. M. (2016). Analisis Spasial Kejadian Demam Berdarah Dengue Berdasarkan Kepadatan Penduduk. Unnes Journal of Public Health, 5(1), 48. https://doi. org/10.15294/ujph.v5i1.9703

Lim, M. L., \& Wallace, M. R. (2004). Infectious diarrhea in history. Infectious Disease Clinics of North America, 18(2), 261-274. https://doi.org/10.1016/j. idc. 2004.01.006

Liu, W., Xia, Y., \& Hou, J. (2019). Health expenditure efficiency in rural China using the super-SBM model and the Malmquist productivity index. International Journal for Equity in Health. https://doi. org/10.1186/s12939-019-1003-5

Mahendradhata, Y., Trisnantoro, L., Listyadewi, S., Soewondo, P., Marthias, T., Harimurti, P., \& Prawira, J. (2017). The Republic of Indonesia health system review. Health Systems in Transition, $7(1)$.
Manton, K. G., Gu, X. L., \& Lamb, V. L. (2006). Change in chronic disability from 1982 to $2004 / 2005$ as measured by longterm changes in function and health in the U.S. elderly population. Proceedings of the National Academy of Sciences of the United States of America, 103(48), 18374-18379. https://doi.org/10.1073/ pnas. 0608483103

Martin, S., Rice, N., \& Smith, P. C. (2008). Does health care spending improve health outcomes? Evidence from English programme budgeting data. Journal of Health Economics, 27(4), 826-842. https://doi.org/10.1016/j. jhealeco.2007.12.002

Menteri Kesehatan Republik Indonesia. (2004). Keputusan Menteri Kesehatan Republik Indonesia Nomor 128 Tahun 2004.

Ministry of Health. (2017). Data dan Informasi Profil Kesehatan Indonesia. Jakarta.

Ministry of Health. (2019). Profil Kesehatan Indonesia 2018.

Murdani, \& Suherlan, A. (2014). Analisis Efektivitas Dan Efisiensi Penyerapan Anggaran Pendidikan Dan Kesehatan Dalam Apbd Kabupaten Aceh Besar Pada Periode 2008-2012. Signifikan: Jurnal IImu Ekonomi, 3(2), 127-148. https:// doi.org/10.15408/sigf.v3i2.2057

Novignon, J. (2015). On the efficiency of public health expenditure in SubSaharan Africa: Does corruption and quality of public institutions matter? Munich Personal RePEc Archive, (39195), 1-21. Retrieved from https://mpra. ub.uni-muenchen.de/39195/2/MPRA_ paper_39195.pdf

Or, Z., Wang, J., \& Jamison, D. (2005). International differences in the impact of doctors on health: A multilevel analysis of OECD countries. Journal of Health Economics, 24(3), 531-560. https://doi. org/10.1016/j.jhealeco.2004.09.003

Parashar, U. D., Gibson, C. J., Bresee, J. S., \& Glass, R. I. (2006). Rotavirus and severe childhood diarrhea. Emerging Infectious Diseases, 12(2), 304-306. https://doi. org/10.3201/eid1202.050006

Peabody, J. W., Shimkhada, R., Tan, C., \& Luck, J. (2005). The burden of disease, economic costs and clinical consequences of tuberculosis in the Philippines. Health Policy and Planning, 20(6), 347-353. https://doi.org/10.1093/heapol/czi041 
Pratama, W., \& Wulandari, S. P. (2015). Pemetaan dan Pemodelan Jumlah Kasus Penyakit Tuberculosis ( TBC ) di Provinsi Jawa Barat dengan Pendekatan Geographically Weighted Negative Binomial Regression, 4(1), 37-42.

Ragil, D. W., \& Dyah, Y. P. (2017). Jurnal of Health Education HUBUNGAN ANTARA PENGETAHUAN DAN KEBIASAAN MENCUCI TANGAN PENGASUH DENGAN KEJADIAN DIARE PADA BALITA Info Artikel. Jhe, 2(1), 39-46.

Reeves, A., Basu, S., Mckee, M., Stuckler, D., Sandgren, A., \& Semenza, J. (2014). Social protection and tuberculosis control in 21 European countries, 1995-2012: A cross-national statistical modelling analysis. The Lancet Infectious Diseases, 14(11), 1105-1112. https://doi. org/10.1016/S1473-3099(14)70927-2

Setyaningsih, W., \& Setyawan, D. A. (2014). PEMODELAN SISTEM INFORMASI GEOGRAFIS (SIG) PADA DISTRIBUSI PENYAKIT DEMAM BERDARAH DENGUE (DBD) DI KECAMATAN KARANGMALANG KABUPATEN SRAGEN Wiwik Setyaningsih, Dodiet Aditya Setyawan. Jurnal Terpadu Ilmu Kesehatan, 3(2), 209-214.

Siregar, F. A. (2004). Epidemiologi Dan Pemberantasan Demam Berdarah Dengue Diindonesia Di Indonesia. USU Digital Library, 1-13.

Siroka, A., Ponce, N. A., \& Lönnroth, K. (2016). Association between spending on social protection and tuberculosis burden: A global analysis. The Lancet Infectious Diseases, 16(4), 473-479. https://doi. org/10.1016/S1473-3099(15)00401-6
Tantular, Bertho, Ruslaela, E., Jaya, I. G. N. M., \& Zulhanif. (2018). PEMETAAN PENYAKIT DIARE DI KOTA BANDUNG DENGAN ANALISIS LOCAL MORAN' S. In Seminar Statistika FMIPA Unpad 2018 (SNS VII).

Tantular, Berto, Nurfauziyah, S., Jaya, I. G. N. M., \& Zulhanif. (2007). Pemodelan resiko relatif penyakit diare di kota bandung dengan regresi spasial.

Thammapalo, S., Chongsuwiwatwong, V., McNeil, D., \& Geater, A. (2005). The climatic factors influencing the occurrence of dengue hemorrhagic fever in Thailand. Southeast Asian Journal of Tropical Medicine and Public Health.

Thielman, N. M., \& Guerrant, R. L. (2004). Acute infectious diarrhea. The New England Journal of Medicine, 350, 38-47. https://doi.org/10.1017/ CBO9780511547454.016

White, H. (1980). A heteroskedasticityconsistent covariance matrix estimator and a direct test for heteroskedasticity. Econometrica: Journal of the Econometric Society, 817-838.

WHO. (2020). Medical Doctor (per 10000 population).

Winarno, K., Hasanbasri, M., Sunjaya, D. K., Kesehatan, D., Kalimantan, P., Studi, P., ... Kesehatan, P. (2013). Evaluasi Kebijakan Pembangunan Puskesmas Pembantu di Propinsi Kalimantan Tengah. Jurnal Kebijakan Kesehatan Indonesia, 02(02), 86-94.

Wooldridge. (2015). Introductory Econometrics (Vol. 1). https://doi. org/10.1017/CBO9781107415324.004 